PROBLEMS

OF MANAGEMENT

IN THE $21^{\text {st }}$ CENTURY

Vol. 10 , No. 1,2015

\section{THE EFFECT OF HARD AND SOFT FACTORS ON THE SUCCESS OF A COMPANY}

\author{
Peter Bóna, Robert Lippert \\ University of Pannonia, Veszprém, Hungary \\ E-mail: hunpoto@gmail.com, robert.lippert@alapeuropa.com
}

\begin{abstract}
What makes a company successful? What kind of instruments may it use to achieve outstanding results? Instruments necessary for effective operation depend remarkably on the current age and the environment surrounding the organisation. Various ages have had their different keys to success. This key has become more and more complex and complicated due to the continuous acceleration of world economy and the fact that distances have become negligible. The aim of this study is to explore, whether companies having an interest in the processing industry use hard or soft success factors as a key to achieve success. In order to do that, the research will identify the possible success factors first. Henceforward it will reveal the effect of the resulting factors on success by logistic regression, which will be examined via the balance scorecard by complementing the four classic aspects - as one of the pioneers - with a fifth one, i.e. sustainability. Thus it will become visible, to what extent strategic, structural, cultural and leadership success factors influence the performance of a company to reach excellence in accordance with the expectations of the owners, the customers, the employees and the social sphere. The results of the research will thereby show the unravelled correlations between the successful operation of a company and the instruments indicating hard and soft success affecting it.
\end{abstract}

Key words: balanced scorecard, culture, leadership, strategy, structure, success factors, sustainability.

\title{
Introduction
}

Numerous research projects (Peters \& Waterman, 1982; Eisenhardt \& Brown, 1998; Joyce, Nohria \& Robertson, 2003; Cserháti \& Szabó, 2014) have already aimed at finding out what makes companies successful. These projects are not unanimous and depend remarkably on the particular age they were done at. T. J. Peters and R. H. Waterman made the first significant step in the research of success (Peters \& Waterman, 1982). Later Eisenhardt and Brown identified time pacing as a main instrument (Eisenhardt \& Brown, 1998). The Evergreen Project explored what organisations assessed by them as successful exactly do (Joyce, Nohria \& Robertson, 2003). Whereas, the latest analyses on success exposed the fact that human resource management plays an outstanding role in achieving success (Szabó \& Dancsecz, 2009; Cserháti \& Szabó, 2014). Borders of countries and continents have become more and more blurred by now, while distances have turned out to be less important. Continents or markets of countries are not separated anymore; therefore competition between companies has become fiercer and much faster than earlier. Following the economic crisis of the past years it has been playing a more significant role how to remain existent and how opportunities can be better exploited in the current fragile system. There are more general factors less dependant on age, such as strategy, the utilisation of key skills so that a company may gain sustainable competitive advantage (Vörös, 2010). Hence, it is determinative, how an organisation puts its internal abilities to use and how it reacts to external challenges (Chikán, 2008). Consequently, the primary task of companies is to be competitive. Their success depends principally on that. 
The instruments applied in the current situation differ from those used earlier, since companies have to maintain their position and achieve success in a different type of economic and social environment that has changed compared to the period preceding the crisis. The research provides an opportunity to bring the deliberate use of instruments in order to achieve success into focus, depending on the current environmental conditions.

Research projects on success are not concordant therefore this research wishes to assess the results of recent decades. Hence, it will become visible, which success factors have been identified in the past. This will help to map, which elements may be used in practice under the current circumstances. So that it can be clearly perceived how an organisation can become successful, how it can achieve an output as high as possible and perform more effectively than its competitors. At the same time an employee can understand too, what motivations lie behind certain decisions and actions.

More and more importance has been attached to soft factors by now (Beer, 2009; Breene \& Nunes, 2011). This research finds it necessary and therefore considers it with high priority, whether this trend exists in case of success factors or still hard factors are dominant in formulating the successful operation and sustainability of a company.

This research aims at finding out what kind of effects components of the concept of strategic management system have on success and to what extent they influence it. Do companies operating in the processing industry still favour the use of hard instruments as opposed soft factors in order to achieve success?

Questions denoting the focus of the research are, as follows:

- Based on which criteria of success may the success of a company be defined?

- Which success factors determine the outstanding achievement, success of a company?

- What kind of correlations may be pointed out between the particular success factors and success criteria, as well as their respective groups?

\section{Methodology of Research}

\section{General Background of Research}

The research is looking for answers to the emerging questions within the scope of strategic management. It will concentrate on the three cornerstones of strategic management: strategy, structure and culture (Barakonyi, 2000) and on the leadership instruments. Which types of groups have a higher impact on the performance, success of a company? Hence success factors will be the independent variables of the research, whereas success will be the dependent variable. The results of research projects (Peters \& Waterman, 1982; Collins \& Porras, 2000; Eisenhardt \& Brown, 1998; Foster \& Kaplan, 2001; Joyce, Nohria \& Robertson, 2003; Spitzer, 2007; Beer, 2009; Breene \& Nunes, 2011) on success concluded in the past years will formulate the basis for identifying success factor variables. Categorization of success factors identified and grouped this way was carried out by factor analysis.

The basis of success is outstanding performance. Therefore, the basis for formulating success criteria is performance measurement. The research will apply the balanced scorecard developed by Kaplan and Norton, based on which it will define success criteria, indicators of success (Table 1) 
PROBLEMS

OF MANAGEMENT

IN THE $21^{\text {st }}$ CENTURY Vol. 10, No. 1, 2015

Table 1. Indicators of success.

\begin{tabular}{|c|c|}
\hline $\begin{array}{ll}\text { - } & \text { Success of Financial Perspective } \\
\text { - } & \text { Changes in profit } \\
\text { - } & \text { Changes in revenue } \\
\text { Changes in costs }\end{array}$ & $\begin{array}{ll}\text { - } & \text { Success of Customer Perspective } \\
\text { - } & \text { Customer satisfaction } \\
\text { - } & \text { Prizes awarded } \\
\text { - } & \text { Changes in number of customers } \\
\text { - } & \text { Customer complaints } \\
\text { - } & \text { Timely deliveries }\end{array}$ \\
\hline $\begin{array}{ll}\text { - } & \text { Success of Internal Processes Perspective } \\
\text { - } & \text { IT investment } \\
\text { - } & \text { Number of deliveries } \\
\text { - } & \text { Patents } \\
\text { - } & \text { Flawless supplier deliveries } \\
& \text { R\&D\&l expenditure }\end{array}$ & $\begin{array}{ll}\text { - } & \text { Success of Learning and Growth Perspective } \\
\text { - } & \text { Co-worker satisfaction } \\
\text { - } & \text { Labour force fluctuation } \\
\text { - } & \text { Improvors of training } \\
& \text { Improment proposals submitted }\end{array}$ \\
\hline $\begin{array}{ll}\text { - } & \text { Success of Sustainability Perspective } \\
\text { - } & \text { Charity donations } \\
\text { - } & \text { Eraduate starting salary } \\
\text { - } & \text { Environmental fines } \\
\text { - } & \text { Recycled waste } \\
\text { - } & \text { Renewable energy } \\
\text { Ratio of women in the management }\end{array}$ & \\
\hline
\end{tabular}

The authors basically differentiate four perspectives in order to measure the performance of a company (Kaplan \& Norton, 2000; Kaplan \& Norton, 2002). However, currently, in the 21 st century a prominent role has been given to sustainability. As a result of that, it is necessary to tackle this issue separately as a fifth perspective. Unlike previous practice, this empirical research will analyse the performance of companies - as one of the pioneers - by taking five perspectives into account. Thereby new, yet unidentified correlations may be explored as opposed to earlier research.

Hypotheses set up as a result of explorative research are, as follows:

Hypothesis No. 1: Companies operating in the processing industry use considerably more hard elements, such as strategic and structural, and less soft elements, such as cultural and leadership factors in order to achieve success.

Hypothesis No. 2: The sustainability success component is primarily affected by strategic success factors.

The McKinsey 7S model is an ideal tool for differentiating the factor groups. Accordingly factors may be subdivided into two groups. The ones that can be explicitly described and are formalised will be ranked among the first type. These are the 'hard' (the so-called hardware) elements. To the second type belong the 'soft' (the so-called software) elements. Their analysis is more difficult and their ascertainment is more complicated. Thinking in terms of elements beyond resources and physical structures reveals itself (Peters \& Waterman, 1982).

- 'Hard elements': strategy, structure, systems

- 'Soft elements': symbolic behaviour, staff, skills, shared values

From the point of view of research strategic and structural success factors belong to the first category, whereas cultural and leadership success factors are grouped in the second.

In the light of independent and dependent variables as well as hypotheses the logic model of the research can be outlined (Figure 1). 


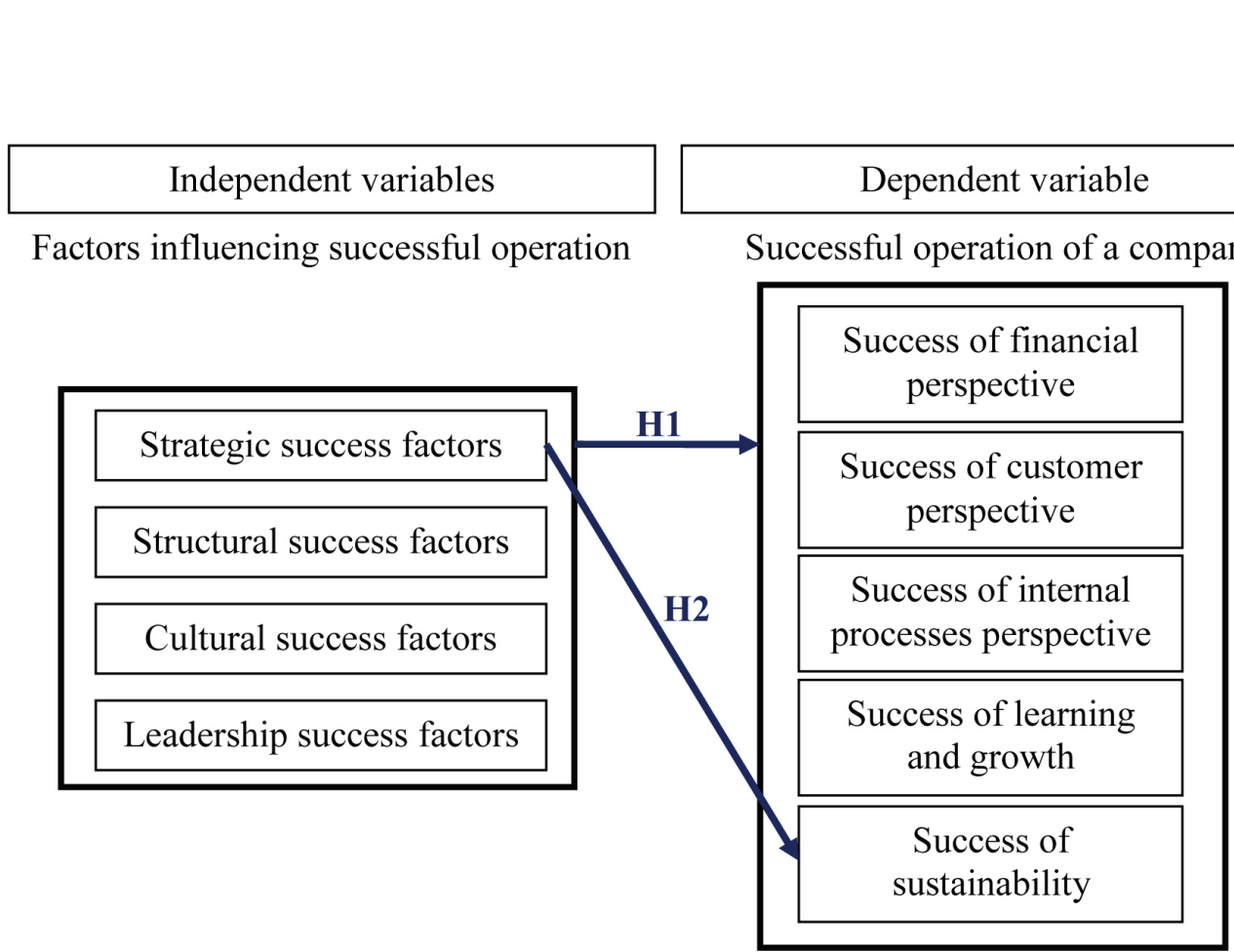

\section{Figure 1: The logic model of the research.}

Sample of Research

Companies having more than 50 employees operating in the processing industry in Hungary have been brought into the focus of the research. There are three main reasons for that. The first one is that these organisations dominate a significant part of the market. Hence, most of the available labour force in Hungary is employed by them. Therefore, it is necessary to bring instruments used by these organisations into focus, so that the research will be able to provide new useful information and correlations to the widest possible group of people. The second main aspect is that companies operating in the processing industry formulated the basis for research of success earlier too, which produced the analysed success factors. Thirdly, because analysed factors, such as strategy, structure, culture and leadership can be interpreted in a broader context in the scope of larger and medium sized companies operating in the processing industry than among smaller undertakings.

\section{Instrument and Procedures}

The questionnaire has been prepared based on the model of the research. Knowledge acquired via the literature on the subject formed the basis for the compilation of the content, which was accompanied by further characteristics and results of companies to be scanned.

109 company leaders reviewed the questionnaire. The participators expressed their views on the clarity and comprehensibility of the questions and on the deliverability of data related to performance. The questionnaire compiled accordingly has been modified based on the observations and suggestions of the interviewed contributors.

The finalised questionnaire was handed over to employees having a managerial role in the targeted companies. Data collection took place between August and November 2014. Altogether 4,411 managers received the questionnaire, out of which 464 were sent back. 230 of them could be used for data analysis. That is a $5.21 \%$ rate. This rate is lower than the average, the reason of which is that the main aspect of the research was objectivity, which played a determinative role 
Peter BÓNA, Robert LIPPERT. The effect of hard and soft factors on the success of a company

PROBLEMS

OF MANAGEMENT

IN THE $21^{\text {st }}$ CENTURY Vol. 10 , No. 1,2015

when collecting performance data. It turned out to be deterring and in many cases leaders filled in performance data imperfectly or with lots of blank spaces. In many instances companies indicated that they were not allowed to fill in and send back the questionnaire, because the supply of performance data fell within the scope of their confidentiality restrictions. On the whole it can be pointed out that the final sample number: 230 exceeds the minimum required number of samples related to statistics methods used with analyses by far.

\section{Data Analysis}

During the analysis the inspection of success factor groups was carried out with factor analysis, whereas the definition of the success component via principal component analysis. The examination of correlations, whether hard or soft elements had a greater influence and which success factor affected the sustainability perspective the most was conducted by logistic regression. Thus the analysis reveals, which components increase the possibility of success related to the whole operation and sustainability of a company and to what extent they improve it.

\section{Results of the Research}

The examination of success factors identified as a result of the theoretical research was carried out via factor analysis. The analysis showed how the suspected variables and their respective groups appear. The Chi-Square Model shows conformity (Table 2). The KaiserMeyer-Olkin Test verified that the variables were suitable for factor analysis, which was confirmed by Bartlett's Test of Sphericity as well (Table 3). Considering the scree plot (Figure 2) five factors may be determined. For the appropriate interpretation of factors their rotation was carried out by the varimax method. After the exclusion of factors not reaching the minimum level of communality the overall quantity of information preserved by factors in the factor structure was 55.42 per cent (Table 4). The rotated factor loading matrix, which finally emerged shows, which components build up factors and with which loading (Table 5). Value only if variable is on factor - factor loading higher than 0.250 .

Table 2. Goodness-of-fit Test.

\begin{tabular}{lll}
\hline Chi-Square & df & Sig. \\
\hline 75.123 & 61 & 0.106 \\
\hline
\end{tabular}

Table 3. KMO and Bartlett's test.

\begin{tabular}{|c|c|c|}
\hline Kaiser-Meyer-Olkin Measure of Sampling Adequacy & & 0.792 \\
\hline \multirow[t]{3}{*}{ Bartlett's Test of Sphericity } & Approx. Chi-Square & 1506.293 \\
\hline & df & 136 \\
\hline & Sig. & 0.000 \\
\hline
\end{tabular}




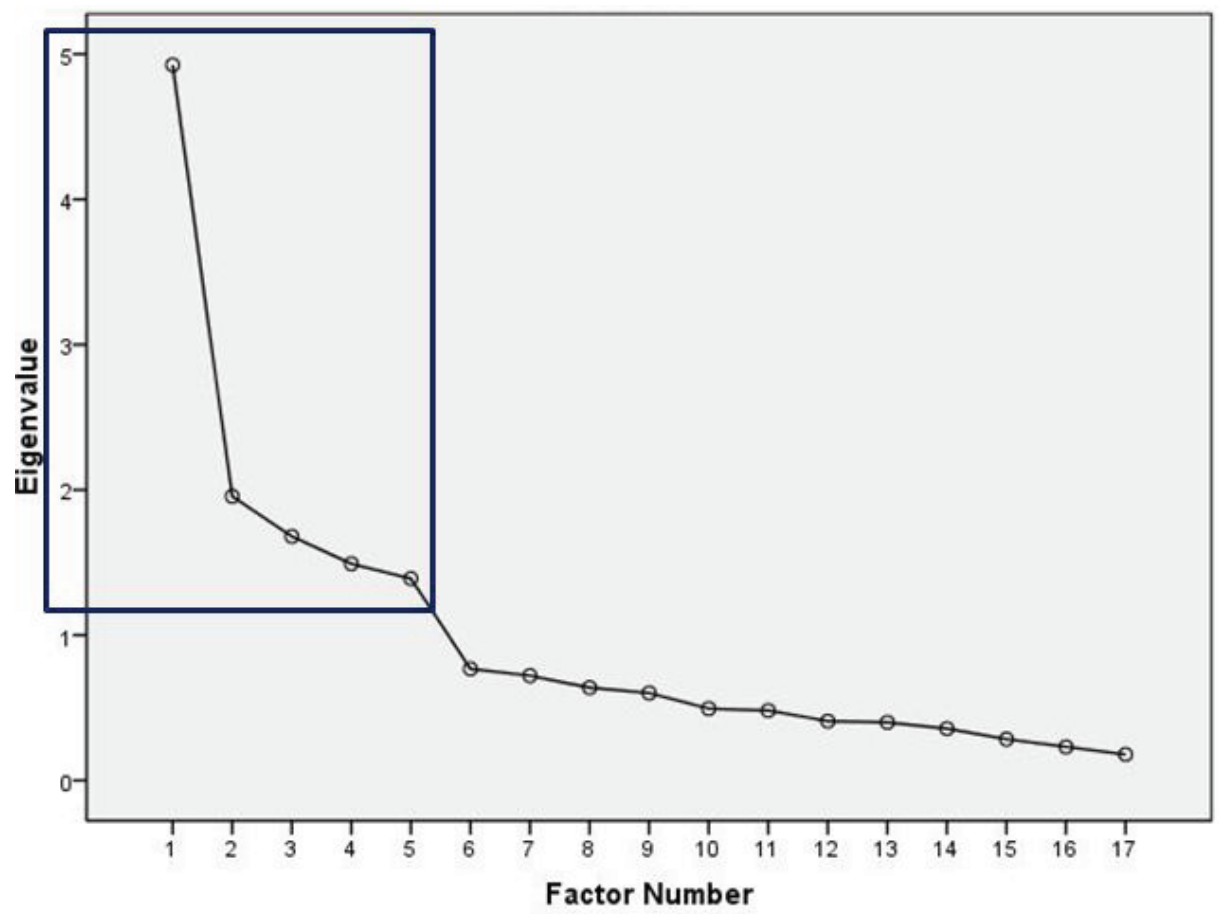

Figure 2: Scree Plot.

Table 4. Total variance explained.

\begin{tabular}{lllllll}
\hline \multirow{2}{*}{ Factor } & \multicolumn{2}{l}{ Initial Eigenvalues } & & \multicolumn{3}{l}{ Rotation Sums of Squared Loadings } \\
\cline { 2 - 7 } & Total & $\%$ of Variance & Cumulative $\%$ & Total & $\%$ of Variance & Cumulative $\%$ \\
\hline 1 & 4.925 & 28.972 & 28.972 & 2.142 & 12.600 & 12.600 \\
\hline 2 & 1.955 & 11.501 & 40.473 & 2.103 & 12.372 & 24.972 \\
\hline 3 & 1.680 & 9.880 & 50.353 & 1.927 & 11.335 & 36.308 \\
\hline 4 & 1.491 & 8.769 & 59.122 & 1.736 & 10.214 & 46.522 \\
\hline 5 & 1.389 & 8.172 & 67.295 & 1.513 & 8.898 & 55.420 \\
\hline
\end{tabular}


PROBLEMS

OF MANAGEMENT

IN THE $21^{\text {st }}$ CENTURY Vol. 10, No. 1, 2015

\section{Table 5. Rotated factor matrix.}

\begin{tabular}{|c|c|c|c|c|c|}
\hline & \multicolumn{5}{|c|}{ Factor } \\
\hline & $\begin{array}{l}\text { External } \\
\text { Strategic } \\
\text { Success } \\
\text { Factors }\end{array}$ & $\begin{array}{l}\text { Internal } \\
\text { Strategic } \\
\text { Success } \\
\text { Factors }\end{array}$ & $\begin{array}{l}\text { Structural } \\
\text { Success } \\
\text { Factors }\end{array}$ & $\begin{array}{l}\text { Cultural } \\
\text { Suc- } \\
\text { cess } \\
\text { Factors }\end{array}$ & $\begin{array}{l}\text { Leadership } \\
\text { Success } \\
\text { Factors }\end{array}$ \\
\hline $\begin{array}{l}\text { Modification of strategy in case of new } \\
\text { social trends }\end{array}$ & 0.737 & & & & \\
\hline Pre-created procedures for transitions & 0.543 & & 0.254 & & \\
\hline $\begin{array}{l}\text { Conformity with the rhythm of market } \\
\text { changes }\end{array}$ & 0.841 & & & & \\
\hline Endeavour to define the pace of business & 0.545 & & & & \\
\hline Development of strategy for a longer term & & 0.529 & & & \\
\hline Strategy known by every co-worker & & 0.833 & & & \\
\hline $\begin{array}{l}\text { Clear communication of strategy to } \\
\text { everyone involved }\end{array}$ & & 0.768 & & & 0.276 \\
\hline $\begin{array}{l}\text { Development of service provider-custom- } \\
\text { er type organisation }\end{array}$ & & & 0.631 & & \\
\hline $\begin{array}{l}\text { Organisational solution for the assess- } \\
\text { ment of proposals }\end{array}$ & & & 0.912 & & \\
\hline $\begin{array}{l}\text { Organisational unity for the implementa- } \\
\text { tion of proposals }\end{array}$ & & & 0.790 & & \\
\hline Teamwork & & & & 0.802 & \\
\hline Multi-skill co-workers & & & & 0.704 & \\
\hline $\begin{array}{l}\text { Organisation of work in an intuitive way } \\
\text { too }\end{array}$ & & & & 0.526 & \\
\hline Management takes part in talent care & & & & & 0.646 \\
\hline $\begin{array}{l}\text { Involvement of employees in the prepara- } \\
\text { tion of decisions }\end{array}$ & & & & & 0.760 \\
\hline $\begin{array}{l}\text { Involvement of employees in the } \\
\text { decision-making }\end{array}$ & & & & & 0.673 \\
\hline $\begin{array}{l}\text { Involvement of employees in the creation } \\
\text { of processes }\end{array}$ & & & & & 0.395 \\
\hline
\end{tabular}

Thus, factors facilitating successful operation in a company may be grouped in five factors. The factor of external strategic success factors which brings changes, fine-tuning and time pacing into focus. The factor of internal strategic success factors, which means long-term plans and raising the awareness for them. The factor of structural success factors, which includes the organisational structural solutions of facilitating service and continuous improvement. The factor of cultural success factors, such as: teamwork, intuitive work organisation and the use of multi-skill labour force. And the factor of leadership success factors as the fifth one, which concentrates on the ways leaders develop their co-workers and subdivide tasks. It is true that five groups have emerged instead of the presupposed four, but this only means that strategic success factors have been separated into two parts: external and internal success factors. In the further analysis these factors will function as independent variables. 
At this stage of the research the analysis of the set up hypotheses was carried out with logistic regression based on two aspects. The first one is the success of companies included in the analysis. It examines, whether success depends on the identified success factors as well as which instruments with which probability improve it. The second aspect is the analysis of sustainability, where the dependant variable is outstanding sustainability performance. It is this variable on which the effect of factors and their degree of influence must be determined. By considering these two aspects the study inspects the improvement of odds ratios generated by success factors earlier identified via factor analyses. Afterwards, it analyses the partial effects of factors, i.e. how many times the influence increases the chances that the performance of the whole company or of its sustainability goes above average, that it becomes outstanding. In order to do that it is necessary to decide what kind of result may be called successful or outstanding. So, as to make this decision data related to companies operating in the processing industry provided a benchmark. Based on the analysis and the assessment of results related to companies included the research determined that a company may be called successful and has an outstanding performance if its overall performance related to all analysed aspects and success criteria exceed the average results of companies present on the market concerning the same aspects by 10 per cent. This applies to sustainability indicators too. Consultations with members of senior management have confirmed this categorisation as well. Accordingly, two groups have been defined based on the standardised success indicator related to the five principal components of indicators describing performance. These two groups are: companies with outstanding performance and those with average or poor performance.

When applying logistic regression for the analysis of company success the sample shows that the Wald statistics used for parameter estimation is significant.

It can be stated in the first phase that if we know nothing about the sample, it can be determined randomly with a 79.1 per cent certainty, whether a company is successful or not. Knowing the variables involved in the research this certainty, however, increases to 80.9 per cent. The significance applies to the whole model after the inclusion of the five factors (Table 6). Following the inclusion of the five independent variables the variable combination of the five independent variables explains 27.7 per cent (Nagelkerke R square $=0.277$ ) of the variance of the dependent variable (Table 7). The 1.8 per cent increase shows that success factors earlier identified have an effect on success and if appropriately used, the chances of achieving success grow by 1.8 per cent (Table 8 ). This value may seem to be low at first sight, but the real business environment is extremely complex and success is thereby the resultant of many internal and external impacts. Hence, this effect of the identified instruments may be evaluated as remarkable.

Table 6. Company success - omnibus tests of model coefficients.

\begin{tabular}{llll}
\hline & Chi-square & df & Sig. \\
\hline Step & 44.973 & 5 & 0.000 \\
\hline Block & 44.973 & 5 & 0.000 \\
\hline Model & 44.973 & 5 & 0.000 \\
\hline
\end{tabular}

Table 7. Company success -model summary.

\begin{tabular}{llll}
\hline Model Summary & -2 Log likelihood & Cox \& Snell R Square & $\begin{array}{l}\text { Nagelkerke R } \\
\text { Square }\end{array}$ \\
\hline Step & 190.650 & 0.178 & 0.277 \\
\hline
\end{tabular}


Peter BÓNA, Robert LIPPERT. The effect of hard and soft factors on the success of a company

PROBLEMS

OF MANAGEMENT

IN THE $21^{\text {st }}$ CENTURY
Vol. 10, No. 1, 2015

Table 8. Company success - classification table difference.

\begin{tabular}{lll}
\hline \multicolumn{3}{c}{ Overall Percentage Correct } \\
\hline Block 0: Beginning Block & Block 1: Method = Enter & Difference \\
\hline $79.1 \%$ & $80.9 \%$ & $1.8 \%$ \\
\hline
\end{tabular}

The second phase revels exactly which success factors provide this influence and in what way. They are the external strategic and structural success factors, which both individually and partially influence the success of a company significantly. The odds ratios (Exp (B)) denote what the chances of success are, if the effect of the other variables is kept under control (Table 9). Companies, which fine-tune their strategy due to changes in social trends, time pace their activity and move with the market will be successful by a 2.324 per cent larger chance than those not dealing with these actions. Nonetheless it may be stated that companies, which consider customer-oriented aspects in their operation and shape up an internal system clearly encouraging development belong to successful companies with a 2.668 greater chance than to unsuccessful ones.

Table 9. Company success - variables in the equation.

\begin{tabular}{lllllll}
\hline & B & S.E. & Wald & df & Sig. & Exp (B) \\
\hline External Strategic Success Factors & 0.843 & 0.240 & 12.365 & 1 & 0.000 & 2.324 \\
\hline Internal Strategic Success Factors & 0.349 & 0.224 & 2.428 & 1 & 0.119 & 1.418 \\
\hline Structural Success Factors & 0.981 & 0.244 & 16.143 & 1 & 0.000 & 2.668 \\
\hline Cultural Success Factors & -0.274 & 0.203 & 1.829 & 1 & 0.176 & 0.760 \\
\hline Leadership Success Factors & 0.413 & 0.226 & 3.353 & 1 & 0.067 & 1.512 \\
\hline Constant & -1.799 & 0.233 & 59.686 & 1 & 0.000 & 0.165 \\
\hline
\end{tabular}

During the examination of outstanding sustainability the analysis followed the same method. The Wald test is significant here as well. The significance applies to the whole model after the inclusion of the five factors (Table 10). The Nagelkerke R square shows that the combination of the five independent variables explains 18 per cent of the variance of the dependent variable (Table 11). The inclusion of independent variables results in a high, 7.4 per cent increase concerning dependent variables. Hit rate accuracy increased to 74.8 per cent from 67.4 per cent (Table 12).

Table 10. Sustainability success - omnibus tests of model coefficients.

\begin{tabular}{llll}
\hline & Chi-square & df & Sig. \\
\hline Step & 31.793 & 5 & 0.000 \\
\hline Block & 31.793 & 5 & 0.000 \\
\hline Model & 31.793 & 5 & 0.000 \\
\hline
\end{tabular}


Table 11. Sustainability success - model summary.

\begin{tabular}{llll}
\hline Model Summary & -2 Log likelihood & Cox \& Snell R Square & Nagelkerke R Square \\
\hline Step & 258.638 & 0.129 & 0.180 \\
\hline
\end{tabular}

Table 12. Sustainability success - classification table difference.

\begin{tabular}{lll}
\hline \multicolumn{3}{c}{ Overall Percentage Correct } \\
\hline Block 0: Beginning Block & Block 1: Method = Enter & Difference \\
\hline $67.4 \%$ & $74.8 \%$ & $7.4 \%$ \\
\hline
\end{tabular}

When analysing the impact table of success factors, the following conclusions can be drawn (Table 13). Strategic and structural success factors have an effect on the success of sustainability. In case of strategic success factors even external ones do. Both their individual and partial effects are significant. Companies, which fine-tune and time pace their strategy belong to successful companies regarding sustainability by a 77.1 per cent greater chance. The customer-oriented organisational structure encouraging improvement proposals increases this chance by 48.6 per cent. This shows that companies, which develop their strategy in details for a longer term and it is known not only by senior management, but by the largest possible number of employees too, increase the chance that the sustainability performance will be outstanding by 81.7 per cent.

Table 13. Sustainability success - variables in the equation.

\begin{tabular}{lllllll}
\hline & B & S.E. & Wald & df & Sig. & Exp (B) \\
\hline External Strategic Success Factors & 0.572 & 0.178 & 10.256 & 1 & 0.001 & 1.771 \\
\hline Internal Strategic Success Factors & 0.597 & 0.182 & 10.778 & 1 & 0.001 & 1.817 \\
\hline Structural Success Factors & 0.396 & 0.167 & 5.654 & 1 & 0.017 & 1.486 \\
\hline Cultural Success Factors & 0.222 & 0.167 & 1.760 & 1 & 0.185 & 1.248 \\
\hline Leadership Success Factors & 0.132 & 0.176 & 0.562 & 1 & 0.453 & 1.141 \\
\hline Constant & -0.856 & 0.158 & 29.203 & 1 & 0.000 & 0.425 \\
\hline
\end{tabular}

\section{Discussion}

Knowing the results the significant effect of external strategy initiates concordance with the Evergreen Research Project as well as with the research results of Eisenhardt and Brown. Joyce and his colleagues pointed out among others during the Evergreen Project that winner companies continuously monitor market situations and fine-tune their strategy in case of changes (Joyce, Noria \& Robertson, 2003). Eisenhardt and Brown concluded at the same time that an organisation must look for ways to anticipate changes. It has to find out how it can give rise to favourable changes, which can be handled by a scenario as a result of being well prepared. Development or the introduction of a new activity alone is, however, not enough for that. Many companies only concentrate on development and they do not pay sufficient attention to transitions. What is done is very important and when it is done, otherwise a good idea may not bring such an advantageous market position it could have induced (Eisenhardt \& Brown, 1999). The emerging correlations do not share the results of Beer, as well as of Breene and 
Peter BÓNA, Robert LIPPERT. The effect of hard and soft factors on the success of a company

PROBLEMS

OF MANAGEMENT

IN THE $21^{\text {st }}$ CENTURY Vol. 10, No. 1, 2015

Nunes, according to which outstanding commitment and soft factors are principal criteria for a company to become successful (Beer, 2009; Breene \& Nunes, 2011). In respect to that they are not primary aspects unlike hard instruments. With companies brought into the focus of analysis hard factors are much more dominant than soft ones. Hence, strategic and structural instruments have the greatest influence on success as opposed to cultural and leadership factors.

\section{Conclusions}

The first hypothesis concentrates on the hard and soft elements set by the McKinsey 7S model, whereas the second hypothesis focuses on the success of sustainability. When assessing the emerging effects of success factors, it may be stated that companies having more than 50 employees operating in the processing industry in Hungary prefer using hard, such as strategic and structural, elements as opposed to soft, i.e. cultural and leadership elements in order to achieve successful operation. Accordingly, if there is a close relationship with the customer, if the organisation develops a separate organisational unit for the assessment and implementation of proposals and if a company immediately takes new social trends into account, prepares itself for transitions, moves with the market, makes its plans for a longer term and clearly communicates the strategy making that happen to all involved, the chances for the business and sustainability success of a company will significantly increase.

\section{References}

Barakonyi, K. (2000). Stratégiai menedzsment. Budapest: Nemzeti Tankönyvkiadó.

Beer, M. (2009). High commitment, high performance: How to build a resilient organization for sustained advantage. San Francisco: John Wiley \& Sons.

Breene, R. T. S., \& Nunes, P. F. (2011). Reinvent your business before it's too late. Harvard Business Review, 89 (1-2), 80-87.

Chikán, A. (2008). Vállalatgazdaságtan, 4. átdolgozott, bövített kiadás. Budapest: AULA Kiadó.

Collins, C. C., \& Porras, J. I. (2000). Built to last: Successful habits of visionary companies (3rd ed.). London: Random House Business Books.

Cserháti, G., \& Szabó, L. (2014). The relationship between success criteria and success factors in organisational event projects. International Journal of Project Management, 32 (4), 613-624.

Eisenhardt, K. M., \& Brown, S. L. (1998). Time pacing: Competing in markets that won't stand still. Harvard Business Review, 76 (2), 59-69.

Foster, R., \& Kaplan, S. (2001). Creative destruction: Why companies that are built to last underperform the market - and how to successfully transform them. New York: Currency Doubleday.

Joyce, W., Nohria, N., \& Robertson, B. (2003). What really works: The 4+2 formula for sustained business success. New York: HarperBusiness.

Kaplan, R. S., \& Norton, D. P. (2000). Balanced scorecard (Eszköz, ami mozgásba hozza a stratégiát BSC - Kiegyensúlyozott stratégiai mutatószám-rendszer). Budapest: KJK-KERSZÖV.

Kaplan, R. S., \& Norton, D. P. (2002). A Stratégiaközpontú szervezet: Hogyan lesznek sikeresek a Balanced Scorecard vállalatok az új üzleti környezetben?. Budapest: Panem Kiadó-IFUA Horváth \& Partner.

Peters, T. J., \& Waterman, R. H. (1982). In search of excellence: Lessons from America's best-run companies. New York: Harper \& Row.

Spitzer, D. R. (2007). Transforming performance measurement: Rethinking the way we measure and drive organizational success. New York: AMACOM.

Szabó, L., \& Csepregi, A. (2009). A gazdasági válság hatása a szervezeti kultúra alakulására - jó irányba megyünk? Harvard Business Manager, 11 (11), 29-34.

Szabó, L., \& Dancsecz, G. (2009). A nemzetközi sportrendezvény-szervezési projektek sikertényezői és a siker megítélésének kritériumai. Vezetéstudomány, 15 (5), 18-31.

Székelyi, M., \& Barna, I. (2002). Túlélökészlet SPSS-hez. Budapest: Tipotex Kiadó.

Vörös, J. (2010). Termelés- és szolgáltatásmenedzsment. Budapest: Akadémiai Kiadó. 
Peter BÓNA, Robert LIPPERT. The effect of hard and soft factors on the success of a company

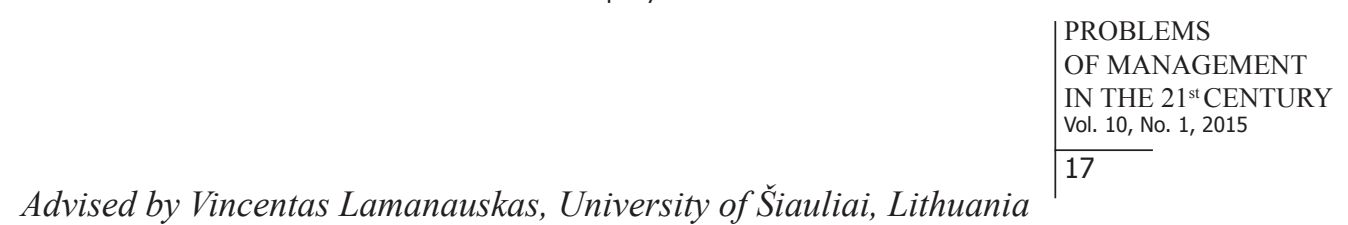

Received: April 04, 2015

Accepted: May 25, 2015

Peter Bóna

PhD Candidate, University of Pannonia, Állvány street 7, Veszprém, Hungary. Email: hunpoto@gmail.com

Robert Lippert

PhD Candidate, University of Pannonia, Állvány street 7, H-8200 Veszprém, Hungary.

Email: robert.lippert@alapeuropa.com

Website: http://www.alapeuropa.com 